\title{
Sexual maturity, spawning and fecundity of king weakfish Macrodon ancylodon, caught off Rio Grande do Sul State (southern coast of Brazil)
}

\author{
Anastácio Afonso JURAS ${ }^{1}$ \& Noriyoshi YAMAGUTI \\ Instituto Oceanográfico da Universidade de São Paulo \\ (Caixa Postal 9075, 01051 São Paulo, SP)
}

\begin{abstract}
- Abstract:: Investigations on the sexual maturity, spawning and fecundity of king weakfish, Macrodon ancylodon, off the southern coast of Brazil (lat. $29^{\circ}$ to $32^{\circ} \mathrm{S}$ ) were carried out from September, 1976, to August, 1977. The sex ratio varied monthly, with slight predominance of males $(51.14 \%)$ over females $(48.86 \%)$. The mean size at first maturity was estimated as $27.4 \mathrm{~cm}$ TL for females and $21.5 \mathrm{~cm}$ TL for males. The macroscopic examination of gonads and analysis of the gonadal index indicated that December and February were the most intensive spawning months. Fish weight proved to be the best predictor data of fecundity: $\mathrm{F}=$ $17056.2500+425.3712 \mathrm{Wt}\left(\mathrm{r}^{2}=0.6434\right)$, were $\mathrm{F}$ is the total number of eggs in both ovaries. The number of eggs of 199 females varied from 59,850 for $33.4 \mathrm{~cm}$ TL fish to over 358,450 for $37.2 \mathrm{~cm}$ TL; the mean fecundity verified was 165,273 eggs per female. Frequency distributions of egg diameter in the ovaries were polymodal, suggesting fractional spawning during the reproduction season.
\end{abstract}

- Descriptors: Sex ratio, Sexual maturity, Spawning seasons, Fecundity, Macrodon ancylodon, Brazil: Rio Grande do Sul.

- Descritores: Proporçāo do sexo, Maturação sexual, Época de desova, Fecundidade, Macrodon ancylodon, Rio Grande do Sul.

\section{Introduction}

Investigations on the life history of Macrodon ancylodon (Bloch \& Schneider, 1801) off the southern coast of Brazil were started by Lara (1951) and afterwards, several researchers have reported on the spawning and fecundity of the king weakfish in the southern coast of Brazil: (Vazzoler, 1963; 1965; Yamaguti, 1967; Vazzoler et al., 1973).

It is expected that the aspects of spawning covered by this study should contribute to the information available, and supply more data on the fecundity of Macrodon ancylodon caught off the southern coast of Brazil.

\section{Material and methods}

Macrodon ancylodon specimens were obtained monthly from commercial landings, chiefly at the port of

(1) Centrais Elétricas do Norte do Brasil S.A. Setor SCN, Bloco B, Quadra 6, Brasilia - CEP 70.710

Contr. $n^{2} 706$ do Inst. oceanogr. da Usp
Santos - São Paulo State - from the catches in waters off Rio Grande do Sul State (lat. $29^{\circ} \mathrm{S}$ to $32^{\circ} \mathrm{S}$ ). Most samples consisted of about 200 fish (Table 1). Stratified subsampling (Gulland, 1971) was used to represent all length classes. About 100 specimens per month were assessed for several other characteristics, of which only the following are relevant to the present work: total length (TL-cm), total weight $(\mathrm{g})$, gonad weight $(\mathrm{g})$, sex, and maturity stage. The paired gonads of female fish were stored in Gilson's fluid (Simpson, 1951) and were used for quantitative estimates of the fecundity and size distribution of eggs. A $2.0 \mathrm{ml}$ capacity Stempel pipette was used to obtain a subsample of the oocytes which had been placed in a known volume of alcohol. For the determination of oocyte diameter distribution, about three hundred oocytes were taken randomly, and measured on square perspex dish at a magnification of $x$ 40 with an ocular micrometer, along a horizontal axis, regardless of their shapes. The accuracy of sampling was tested by taking five replicates of the subsamples. All the oocytes in the subsamples were counted but for fecundity estimates only yolked oocytes greater than $170 \mu \mathrm{m}$ were considered (yolked ova according to Vazzoler, 1963).

The scale of maturity was based on that described in Laevastu (1971), composed of seven stages, 
corresponding to that used by Yamaguti, 1967, in which the size and colour of the gonads, and oocytes were taken into consideration. A short description of the gonadal macroscopic characteristics at the different developmental stages is given in Table 2 .

Table 1. Number of fishes examined by range of total length $(\mathrm{mm})$ of Macrodon ancylodon September/76 and August/77 period

\begin{tabular}{lcc}
\hline Months & $\begin{array}{c}\text { Number } \\
\text { of fish }\end{array}$ & $\begin{array}{c}\text { Range of total } \\
\text { length (mm) }\end{array}$ \\
\hline September $/ 76$ & 349 & $130-373$ \\
October & 195 & $185-420$ \\
November & 216 & $185-375$ \\
December & 216 & $145-401$ \\
January/77 & 196 & $170-370$ \\
February & 165 & $215-376$ \\
March & 213 & $178-340$ \\
April & 193 & $153-383$ \\
May & 229 & $160-382$ \\
June & 225 & $135-422$ \\
July & 202 & $123-354$ \\
August & 257 & $133-384$ \\
Totals & 2656 & $123-422$ \\
\hline
\end{tabular}

Sex ratio was calculated from the estimated total number of males and females in the catches. The relative frequency of each sex are presented in Figure 2.

Resting ovaries cannot easily be distinguished from juvenile ones. Therefore, the length at first maturity was estimated based only on data of the peak spawning season, when most adult fish would have mature gonads. Length at first maturity was acertained from males and females collected in December and February. They were separated into two maturity classes: immature (stages I and II) and mature fish (stages III, IV, V and VI). The relative percentages were plotted per $10 \mathrm{~mm}$ length class (Fig. 3).

The spawning season was deduced both from monthly occurrence of maturity stages (Fig. 4) and monthly averages of gonadal index of both sexes as presented in Figure 5. The gonadal index (GI) used in this study is given by the following mathematical expression:

$$
G I=\frac{\text { WO }}{W_{t}} \times 10^{3}
$$

where: WO is the weight of both ovaries in grams and Wt is the total weight of the fish in grams. The GI was calculated for males and females individually and the mean values analyzed monthly (Fig. 5) and for different developmental stages (Fig. 6).

Fecundity, defined as the potential number of mature eggs (= yolked ova, over $170 \mu$ m diameter) - that could be spawned during a reproductive season, was estimated from ovaries containing clearly discernible eggs (stages IV, $\mathrm{V}$ and VI). Regressions were used to examine relationships of total fecundity on total weight (grams); on total length (centimeters); on ovary weight (grams). The results from December and February are shown in Figure 7.

The oocyte size frequencies obtained from stages III, IV, V and VI in December and February are presented in Figure 8.

Table 2. Macroscopic characteristics of testes and ovaries at different developmental stages and average values of gonad index (GI) (numbers of specimens examined in parentheses)

\begin{tabular}{|c|c|}
\hline Developmental Stage & Macroscopic char acter ist ics \\
\hline virgin & $\begin{array}{l}\text { Testes and ovaries less than a half length } \\
\text { of body cavity, thread-l ike, glassy or pale. } \\
G 1=0.08 \cdot 0.52 \text { (184) } \delta \delta \\
G 1=0.14 \cdot 0.36 \text { (473) } Q Q\end{array}$ \\
\hline $\begin{array}{l}11 \text { Developing virgin } \\
\text { or recovering }\end{array}$ & $\begin{array}{l}\text { Testes and ovaries translucent, about a half } \\
\text { length of the body cavity; cocytes can be } \\
\text { seen by magnifying glass. } \\
\mathrm{GI}=0.12-0.82 \text { (322) } \delta \delta \\
\mathrm{GI}=0.31 \cdot 0.76 \text { (433) } Q Q\end{array}$ \\
\hline III Developing & $\begin{array}{l}\text { Testes and ovar ies opeques; ocytes visible } \\
\text { to naked eye. } \\
\mathrm{GI}=0.20-0.67 \text { (264) } \delta \delta \\
\mathrm{GI}=0.66-3.51 \text { (419) } Q Q\end{array}$ \\
\hline IV Developed & $\begin{array}{l}\text { Testes firm, becoming whiter; ovar ies yellow, } \\
\text { large cocytes visible. } \\
G 1=0.42 \cdot 0.88(129) \delta \delta \\
G 1=2.09 \cdot 5.49(262) \subseteq Q\end{array}$ \\
\hline V Ripe & $\begin{array}{l}\text { Testes fills body cavity, pure white; hyal ine } \\
\text { ocytes present, producing speckled appearance. } \\
G 1=0.06-0.96 \text { (38) } \delta \delta \\
G 1=3.22 \cdot 9.28 \text { (32) } Q Q\end{array}$ \\
\hline V1 Ruming & $\begin{array}{l}\text { Mitt and oocytes runs fran vent on stight } \\
\text { pressure; parts becoming soft. } \\
G I=0.50-1.11 \text { (31) } \delta \delta \\
G 1=5.02-12.64 \text { (44) } Q Q\end{array}$ \\
\hline VII spent & $\begin{array}{l}\text { Testes flaceid, grey-brown, there may be a little } \\
\text { residual milt; ovaries flaccid, dark red, less } \\
\text { than half of body cavity; a few large residual } \\
\text { ocytes visible. }\end{array}$ \\
\hline
\end{tabular}

\section{Results}

The size of immature fish varied for females from 13 to $36 \mathrm{~cm} \mathrm{TL}$, and for males from 13 to $32 \mathrm{~cm} \mathrm{TL}$. Mature fish varied from 25 to $42 \mathrm{~cm}$ TL and 19 to $38 \mathrm{~cm}$ TL for females and males, respectively (Fig. 1).

\section{Sex composition}

Sex ratios fluctuated monthly (Fig. 2): males predominated from September to March (variation from 51.48 to $72.26 \%$ ), and females from April to July (variation from 53.89 to $60.60 \%$ ). The mean annual sex ratio (females: males) was 0.96 . 


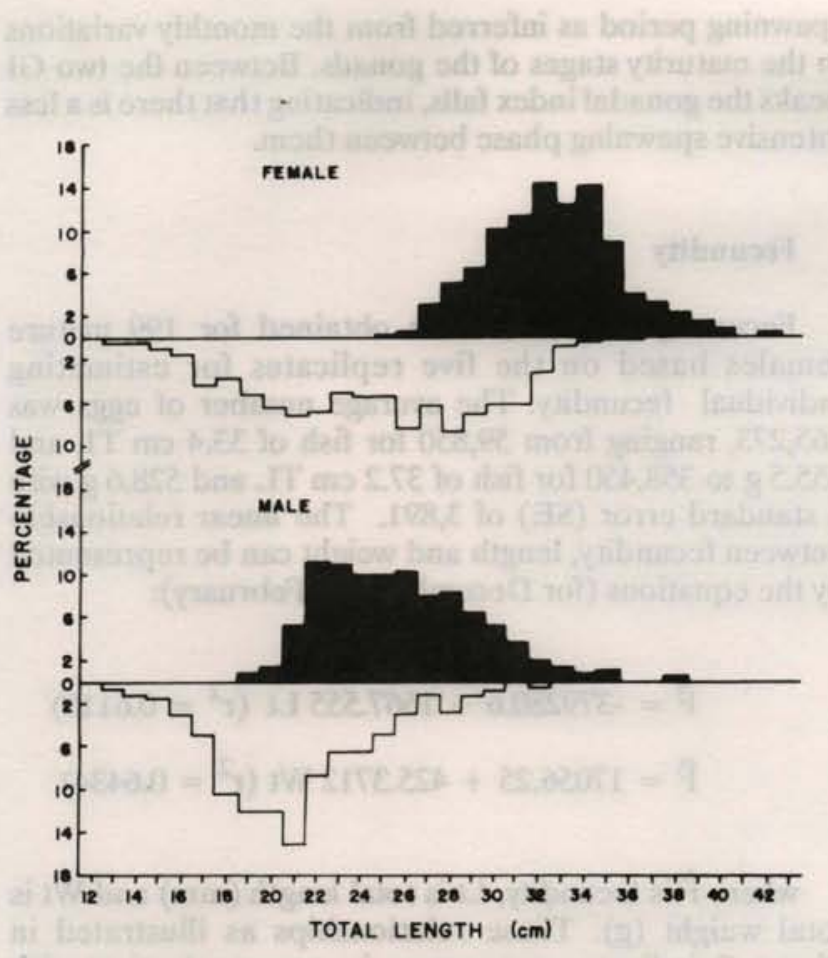

Fig. 1. Length frequencies histograms of immature (show in white) and mature (black) female and male fish of Macrodon ancylodon caught during the period from September 1976 to August 1977.

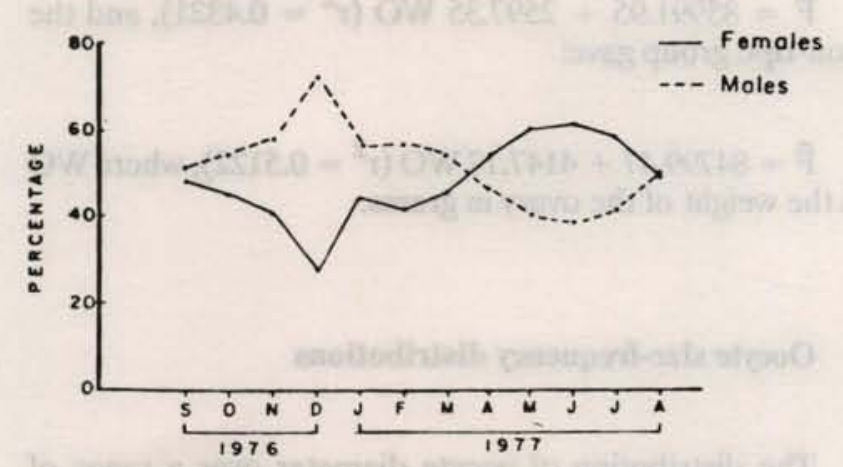

Fig. 2. Relative frequency of females and males of Macrodon ancylodon.

\section{Size at sexual maturity}

No female less than $25 \mathrm{~cm}$ TL and all greater than 31 $\mathrm{cm}$ TL, and no male less than $19 \mathrm{~cm}$ TL and all greater than $24 \mathrm{~cm}$ TL were sexually mature. Estimated mean sizes of sexual maturity (LT 50\%) were: for females $27.4 \mathrm{~cm} \mathrm{TL}$, and for males $21.5 \mathrm{~cm}$ TL.

\section{Time and mode of spawning}

The spawning season of king weakfish was deduced from relative monthly occurrence of gonadal stages of females and males (Fig. 4). Fish in stage I occurred more frequently during winter than summer. High rates of fish in stage II were caught from March to July, decreasing after August. Fish in stage III constituted $51 \%$ of the sample in August, which suggests that the fish in stage II in previous months were developing into stage III, these fish matured into stage IV which resulted in high representation in the samples collected in November $(50 \%)$ and February (52\%). The occurrence of fish in stages V and VI in November could indicate the onset of spawning activity which seemed to have continued until April. Two peaks of high spawning activity were observed: one in December and other in February, indicating that king weakfish is a fractional spawner.

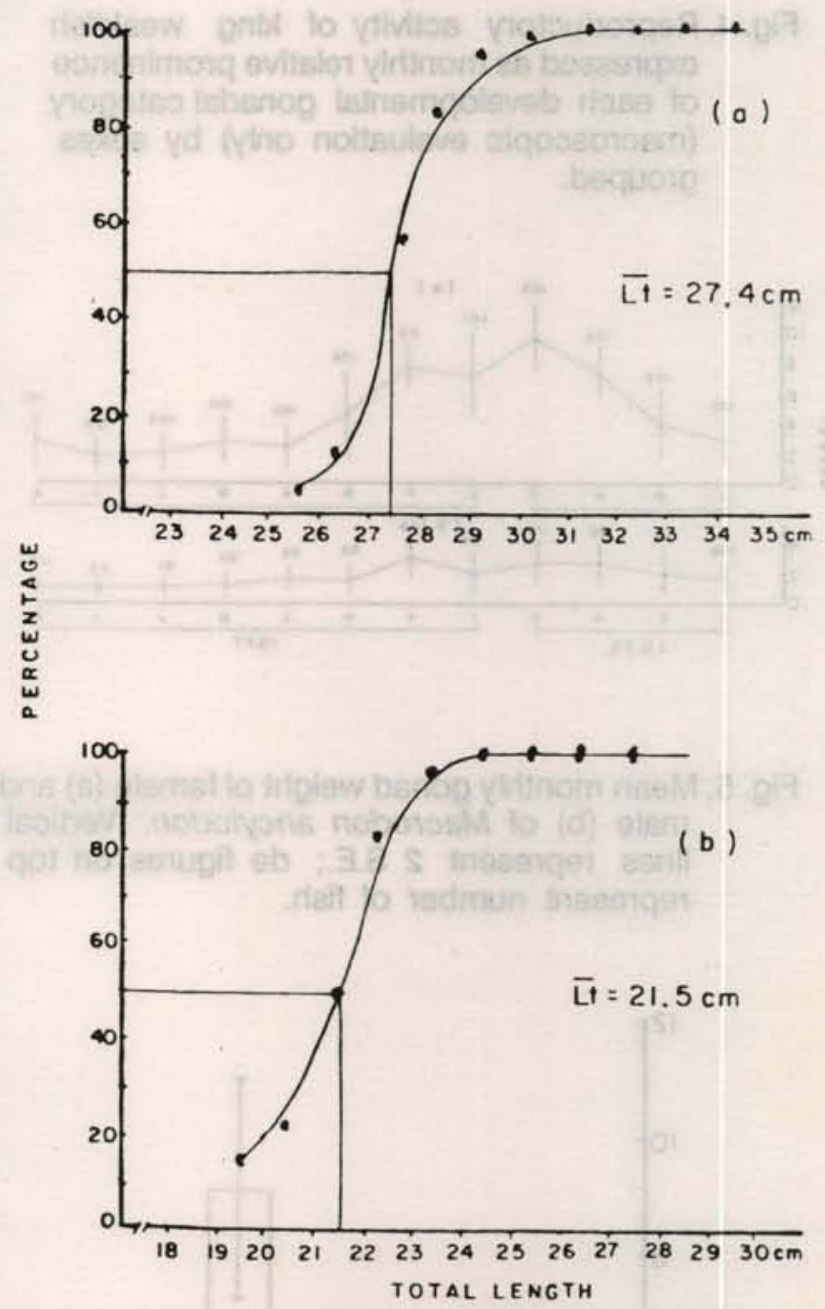

Fig. 3. Length at first maturity of king weakfish collected from November/76 and February/77 (a) females, (b) males.

\section{Variation in gonad weight}

Monthly changes in the mean gonadal index (GI) are shown in Figure 5. Variations in the mean weights of the ovary during the maturation cycle are shown in Figure 6. There were two peaks of gonadal index coincident for females and males, one in December and another in February. The high GI values seem to agree with the 


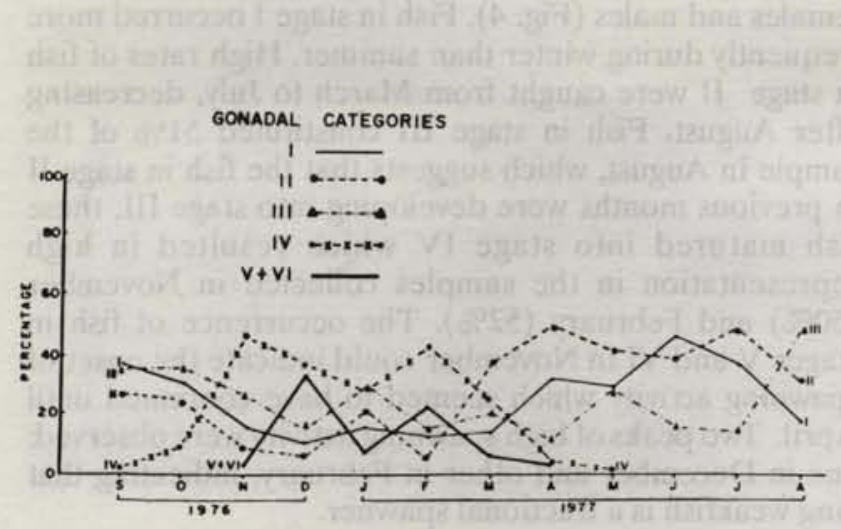

Fig. 4. Reproductory activity of king weakfish expressed as monthly relative prominence of each developmental gonadal category (macroscopic evaluation only) by sexes grouped.
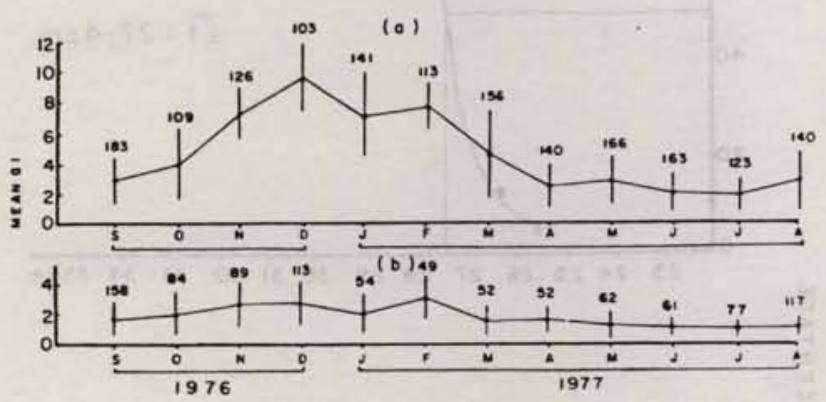

Fig. 5. Mean monthly gonad weight of female (a) and male (b) of Macrodon ancylodon. Vertical lines represent 2 S.E.; de figures on top represent number of fish.

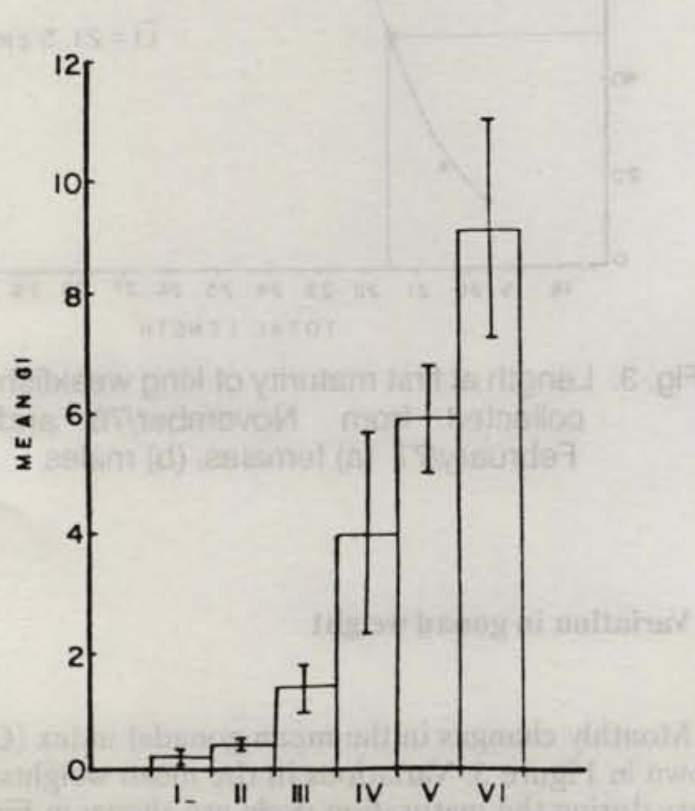

Fig. 6. Mean 2 S.E. GI at different developmental stages of females. spawning period as inferred from the monthly variations in the maturity stages of the gonads. Between the two GI peaks the gonadal index falls, indicating that there is a less intensive spawning phase between them.

\section{Fecundity}

Fecundity estimates were obtained for 199 mature females based on the five replicates for estimating individual fecundity. The average number of eggs was 165,273 , ranging from 59,850 for fish of $33.4 \mathrm{~cm}$ TL and $355.5 \mathrm{~g}$ to 358,450 for fish of $37.2 \mathrm{~cm}$ TL and $528.6 \mathrm{~g}$ with a standard error (SE) of 3,891 . The linear relationship between fecundity, length and weight can be represented by the equations (for December and February):

$$
\begin{aligned}
& \hat{\mathrm{F}}=-379280.6+1667.555 \mathrm{Lt}\left(\mathrm{r}^{2}=0.6118\right) \\
& \hat{\mathrm{F}}=17056.25+425.3712 \mathrm{Wt}\left(\mathrm{r}^{2}=0.6434\right)
\end{aligned}
$$

where $\hat{\mathrm{F}}$ is fecundity, $\mathrm{Lt}$ is total length ( $\mathrm{mm})$ and $\mathrm{Wt}$ is total weight $(\mathrm{g})$. These relationships as illustrated in Figure 7 indicate an increase in egg production with increase in length and weight. Total weight proved to be the best predictor of fecundity. When fecundity is plotted against the weight of the ovary, an interesting relationship becomes apparent between those fish considered to be in a ripe group (stages $\mathrm{V}$ and $\mathrm{VI}$ ) and those in a non-ripe group (stage IV) (Fig. 7). The ripe group gave the relationship (for December and February):

$\hat{\mathrm{F}}=85991.95+2597.35$ WO $\left(\mathrm{r}^{2}=0.4321\right)$, and the non-ripe group gave:

$\hat{\mathrm{F}}=84799.47+4147.17 \mathrm{WO}\left(\mathrm{r}^{2}=0.5122\right)$, where WO is the weight of the ovary in grams.

\section{Oocyte size-frequency distributions}

The distribution of oocyte diameter over a range of maturity stages is shown in Figure 8. The distribution of the oocytes diameter within an ovary was similar to that illustrated for other fractional spawning fishes (Macer, 1974). At all ovarian stages described as developing, a group of ripening oocytes was discernible; this group grows in size and relative proportions (presumably as smaller ones move into the ripening group) as GI increases (see Tab. 2). Thus in the frequency distribution of oocytes for December (Fig. 8) in the developing stage, the last modal group of the oocytes ranged from 540 to $660 \mu \mathrm{m}$, in the developed stage the modal group ranged from 780 to $900 \mu \mathrm{m}$ and in the ripe stage the last mode ranged from 1140 to $1260 \mu \mathrm{m}$. Finally, in the running stage the last modal group ranged from 1440 to $1560 \mu \mathrm{m}$. In February, we observed the same pattern of the modal groups described in December, but the oocyte diameters in February were larger than those observed in December, as summarized in Figure 8. 

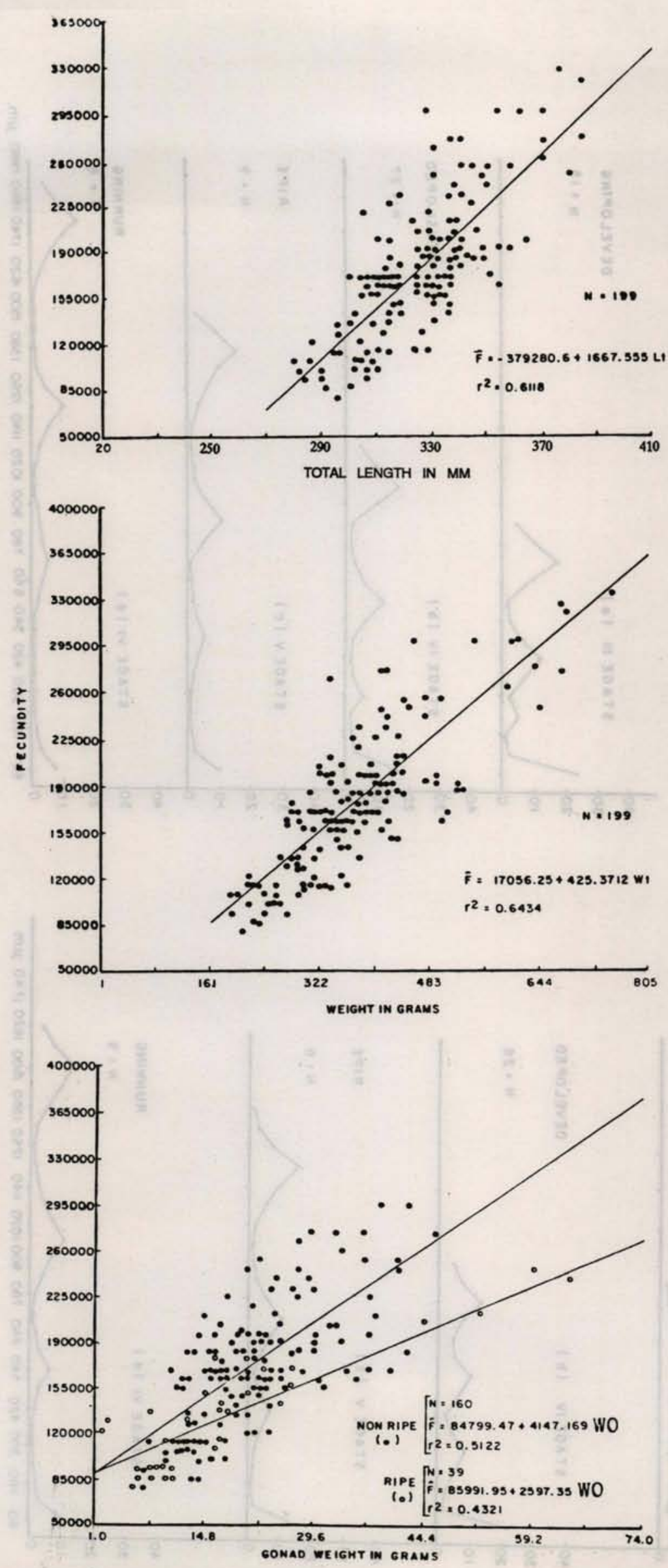

Fig. 7. Relationship between fecundity and three predictors: (top) length; (middle) weight and (bottom) gonad weight of 199 king weakfish for December and February months. 

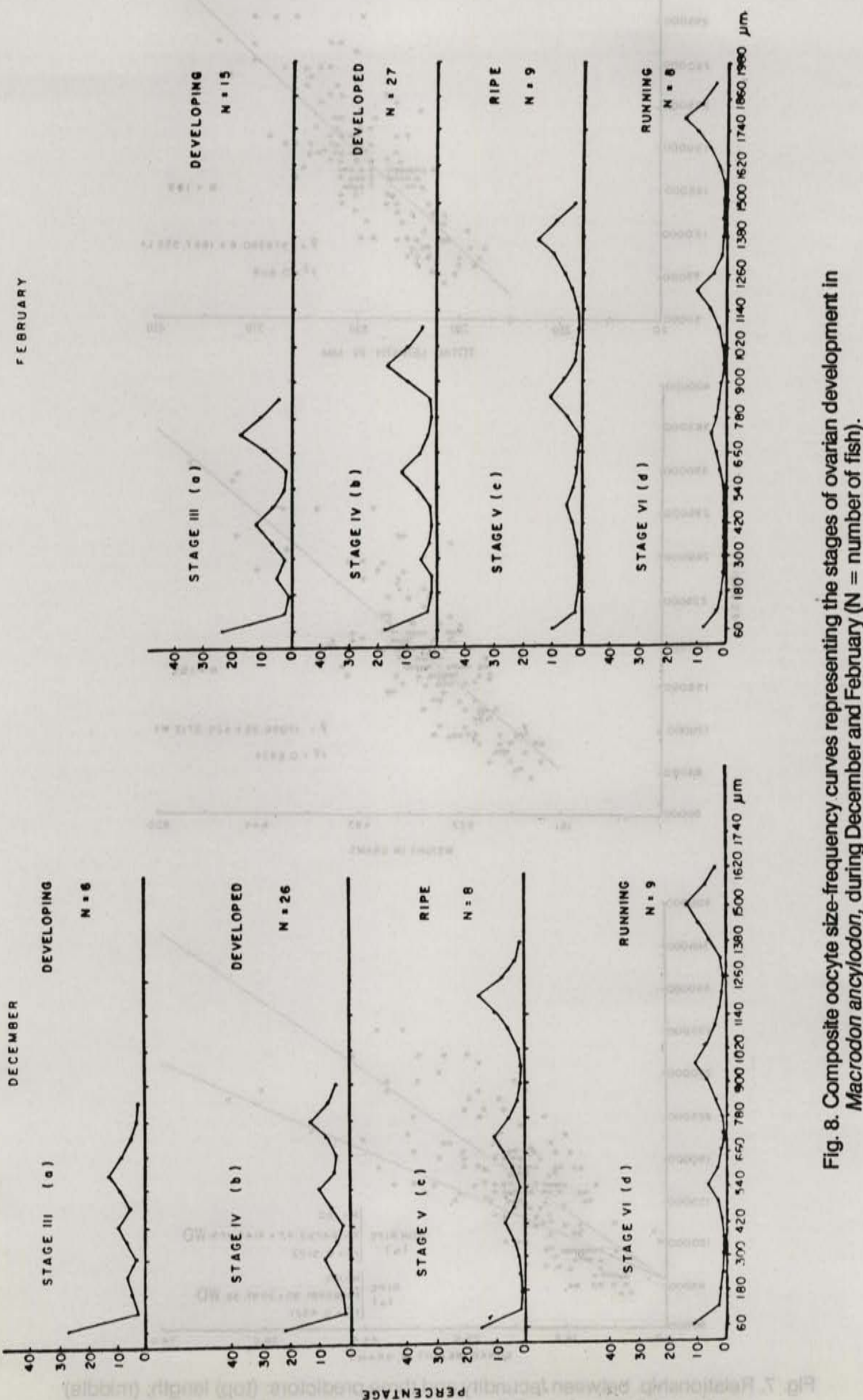


\section{Discussion and conclusions}

In relation to maximum length of fish, we observed that females attained larger size ( $42 \mathrm{~cm}$ TL) than males $(39 \mathrm{~cm}$ TL) (see Fig. 1), and this fact is related to the prior attainment of sexual maturity of males, as observed for other species of fish (Templeman et al., 1978).

\section{Sex composition}

Nikolsky (1969) stated that there is often a surplus of males in the spawning groups of some species, and cited a number of examples by way of explanation of this phenomenon. He also stated that sex ratio can show a regular change during the spawning migration, males predominating at the start, after which the ratio becomes $1: 1$, and then females predominate. But in our study there was a predominance of males during the spawning season and of females afterward. Yamaguti (1967) observed very similar sex ratio variations and probably there are more males than females in adult populations at the spawning area during the spawning season.

Higher occurrence of females from April to July can be attributed to feeding migration and to the movement of the fishing fleet accompanying them, as suggested by Yamaguti (op. cit.).

\section{Size at first maturity}

Lara (1951) found that $50 \%$ of the females in the size of $25.5 \mathrm{~cm}$ SL of the king weakfish population off Santos (SP) were mature. Vazzoler (1963) and Yamaguti (1967) found $26 \mathrm{~cm}$ TL and $25 \mathrm{~cm}$ TL for females caught off Rio Grande do Sul coast, respectively. In this work $21.5 \mathrm{~cm}$ TL (males) and $27.4 \mathrm{~cm}$ TL (females) were the sizes verified at first maturity. The differences observed with the results obtained by other investigators may reflect different growth rates occuring in different sampling periods and in various areas from those investigated by Lara.

\section{Variations in gonad weight; time and frequency of spawning}

A study of the monthly changes in the gonadal index has been used to determine the spawning period for many species (Stequert, 1976). The two peaks of gonadal index values observed in male and female samples in December and February suggest fractional spawning. This view is also supported by the presence of the high frequency of gonads in stages V-VI in December and February. These results agree with the observations of Vazzoler (1963), Yamaguti (1967) and Vazzoler et al. (1973) that king weakfish spawn from late spring until summer in Rio Grande do Sul State.

\section{Fecundity}

Our estimate of fecundity based on counts of maturing oocytes in ripe or nearly ripe fish, apparently was greater (average fecundity $=165,273$ eggs) than those verified by Vazzoler (1963) (average fecundity $=120,579$ eggs). The difference between these values may have been due primarily to the different sampling periods and to the size of the fish examined; it can be also due to variations in the biotic or abiotic environmetal factors affecting fecundity directly or indirectly (Nikolsky, 1969; Bagenal, 1973), and to the fractional spawning behavior of the king weakfish which would also increase the variability in the number of ova estimated for fish of the same size range (Bagenal \& Braum, 1971).

The comparison of correlation coefficients in this work shows that fecundity can be explained in terms of weight $\left(r^{2}=0.6434\right)$ almost as well as by length $\left(r^{2}=0.6118\right)$. Vazzoler (1963) obtained correlation between fecundity/total length $\mathrm{r}^{2}=0.69$ and fecundity/weight $\mathrm{r}^{2}=$ 0.64 , for king weakfish caught in the same area; MacGregor (1968) said that the relationship of length and weight to egg production is masked in many species of fish, because egg production occurs over a relatively short range in size, and because variation in number of eggs produced at each length is great; this fact can explain our results when compared with those of Vazzoler (op. cit.).

In this work, the difference verified in the regression of fecundity on gonad weight in ripe and non-ripe maturity groups, can be attributed to an increase in weight of ovary in the ripe group caused by sudden hydratation of eggs, without increase of fecundity.

Hunter \& Goldberg (1980) have improved a method for the estimation of annual fecundity for females in partial spawning species, such as Engraulis mordax and determined batch fecundity and spawning frequency. For the estimation of batch fecundity they counted hydrated oocytes and for determinating the spawning frequency they used the incidence of postovulatory follicles in ovaries. Later Alheit et al. (1984) applied the same methods sucessfully in Engraulis ringens.

Hunter \& Leong (1981) estimated that E. mordax spawns about 20 times per year and a similar figure was obtained for the sciaenid Seriphus politus by DeMartini \& Fountain (1981). Hunter et al. (1984) stressed that species with indeterminate annual fecundity (partial spawners) spawns so repeatedly that the only methods for estimating the annual fecundity were by batch fecundity and spawning frequency.

For Macrodon ancylodon the estimates of the standing stock of oocytes over $170 \mu \mathrm{m}$ are roughly three times the batch fecundity and do not represent the annual fecundity of each female.

\section{Oocyte size-frequency distributions}

Eggs in the gonad of pre-spawning fish present a polymodal distribution of diameters, suggesting that they are spent successively within each spawning season; these results are similar to those described by Vazzoler (1963).

Species such as the king weakfish are referred to as fractional spawners and the problem with this reproductive category is how to identify the oocytes which are potencially capable of being released in the current season. The acquisition of yolk is one of the most obvious signs of oocyte development, a common criterion adopted also by other authors in studies of reproduction in fishes (Vazzoler, 1963; Macer, 1974).

Nikolsky (1969) showed that the quality and size of the eggs, and the yolk content, are dependent on the age and the food supply and can vary from year to year; the same author stated that the tendency for the increase of egg size and decrease of fecundity during the course of spawning, can be an adaptation to the poorer food supply in the environment for the larvae, and the eggs with more yolk reserve would provide food for the future larvae for a longer period of poor supply in the sea. This fact would explain the greater oocyte diameters in the more advanced 
mode in February with reduction of fecundity (second spawning peak) from that of the first spawning peak (December) observed in Macrodon ancylodon. Ware (1975) observed a similar tendency where winter and spring spawners species must produce larger eggs than summer spawning.

\section{Acknowledgments}

The authors are very grateful to Ilidia da Ascenção Garrido Martins-Juras (MSc) for many helpful suggestions in the preparation of the manuscript. The research was partially supported by the Conselho Nacional de Desenvolvimento Científico e Tecnológico CNPq.

\section{References}

ALHEIT, J.; ALARCON, V. H. \& MACEWICZ, B. J. 1984. Spawning frequency and sex ratio in Peruvian anchovy. Calif. coop. ocean. Fish. Invest. Rep., 25:4352.

BAGENAL, T. B. 1973. Fish fecundity and its relations with stock and recruitment. Rapp. P.-v. Réun. Cons. perm. Int. Explor. Mer, 164:186-198.

\& BRAUM, E. 1971. Eggs and early life history. In: Ricker, W. E.,ed. Methods for assessment of fish production in fresh waters. $2^{\text {nd }} \mathrm{ed}$. London, International Biological Programme. p.166-198.

DE MARTINI, E. E. \& FOUNTAIN, R. K. 1981. Ovarian cycling frequency and batch fecundity in the queenfish, Seriphus politus: attributes representative of serial spawning fishes. Fishery Bull. natn. mar. Fish. Serv, U.S, 79(3):547-560.

GULLAND, J. A. 1971. Manual de metodos para la evaluación de las poblaciones de peces. Zaragoza, Edit. Acribia/FAO. 164p.

HUNTER, J. R. \& GOLDBERG, S. R. 1980. Spawning incidence and batch fecundity in northern anchovy, Engraulismordax. Fishery Bull. natn. mar. Fish. Serv., U.S. 77(3):641-652.

\& LEONG, R. 1981. The spawning energetics of female northern anchovy, Engraulis mordax. Fishery Bull, natn. mar. Fish. Serv., U.S. 79(2):215-230.

; LO, N. C. H. \& LEONG, J. H. 1984. Batch fecundity in multiple spawning fishes. In: Lasker, R., ed. An egg production method for estimating spawning biomass of pelagic fish: application to the northern anchovy, Engraulis mordax, U.S. Dep. Commer., NOAA Administrative Report LJ-84-37.p.204-246.
LAEVASTU, T. 1971. Manual de metodos de biologia pesquera. Zaragoza, Edit. Acribia/FAO. 243 p.

LARA, F. J. S. 1951. A study of the life history of Macrodon ancylodon (Bloch \& Schneider) a sciaenid fish occurring on the coast of southern Brazil. Anais Acad. bras. Ciênc., 23(3):291- 322.

MACER, C. T. 1974. The reproductive biology of the horse mackerel Trachurus trachurus (L.) in the North Sea and English Channel. J. Fish. Biol., $6(3): 415-438$.

MacGREGOR, J. S. 1968. Fecundity of the northern anchovy, Engraulis mordax Girard. Calif. Fish Game, 54:281-288.

NIKOLSKY, G. V. 1969. Theory of fish population dynamics as the biological background for rational exploitation and management of fishery resources. Edinburg, Olivier \& Boyd. 323 p.

SIMPSON, A. C. 1951. The fecundity of the plaice. Fisheries Invest., Lond., ser. 2, 17(5):1-27.

STEQUERT, S. 1976. Étude de la maturité sexualle, de la ponte et de la fecondité du listao (Ketsuwonus pelamis) de la côte nord-ouest de Madagascar. Cah. ORSTOM, sér. Océanogr., 14(3):227- 247.

TEMPLEMAN, W.; HODDER, V. M. \& WELLS, R. 1978. Age, growth, year-class strength, and mortality of the haddock, Melanogrammus aeglefinus, on the southern Grand Bank and their relation to the haddock fishery of this area. Res. Bull. int. Commn NW Atlantic Fish., (13):31-52.

VAZZOLER, A. E. A. de M. 1963. Sobre a fecundidade e a desova da pescada-foguete. Bolm Inst. oceanogr., S Paulo, 13(2):33-40.

1965. Relative spawning power of Macrodon ancylodon (Bloch) population in the southern coast of Brazil. Anais Acad. bras. Ciênc., 37 (supl.):365-370.

; ZANETI, E. M. \& KAWAKAMI, E. 1973. Estudo preliminar sobre o ciclo de vida dos Sciaenidae. Parte I, Composiçāo da população em classes de comprimento e aspectos da reprodução. Publção esp. Inst. oceanogr., S Paulo, (3, pt. 1):241- 291.

WARE, F. M. 1975. Relation between egg size, growth, and natural mortality of larval fish. Res. Ed. Can., 32:2503-2512.

YAMAGUTI, N. 1967. Desova da pescada-foguete, Macrodon ancylodon. Bolm Inst. oceanogr., S Paulo, 16(1):101-106. 